\title{
The knotty politics of ginseng conservation and management in Appalachia
}

\author{
Justine Law ${ }^{1}$ \\ Sonoma State University, USA
}

\begin{abstract}
American ginseng (Panax quinquefolius) is a long-lived understory species in Appalachian forests and the most valuable medicinal plant in North America. Indeed, "digging" for ginseng roots is an important livelihood strategy throughout Appalachia. Increasingly, however, concern for ginseng populations is escalating, and state and federal policies have introduced new harvesting restrictions, as well as new law enforcement efforts that target ginseng diggers. Here I am interested in troubling the high-profile narrative that ginseng populations are crashing due to the unscrupulous practices of Appalachian diggers. I draw on ecological research, historical documents, and my own ethnographic fieldwork to argue that we need a fuller understanding of both ginseng population demographics and the potential causes for ginseng decline, before we embrace a narrative that disenfranchises those who depend on and, in many cases, have helped steward this enigmatic plant. This research speaks to growing tensions between rural livelihoods and conservation efforts worldwide.
\end{abstract}

Keywords: Appalachia, forest livelihoods, ginseng, plant conservation, political ecology

\section{Résumé}

Le ginseng américain (Panax quinquefolius) est une espèce de sous-bois des forêts des Appalaches et la plante médicinale la plus précieuse d'Amérique du Nord. En effet, la «fouille» des racines de ginseng est une stratégie de subsistance importante dans les Appalaches. De plus en plus, cependant, les préoccupations en matière de conservation du ginseng augmentent, et les politiques fédérales et des États ont introduit de nouvelles restrictions de récolte, ainsi que de nouveaux efforts d'application de la loi qui ciblent les cueilleurs de ginseng. Je cherche ici à contester le récit très médiatisé selon lequel les effectifs de cette plante à longue durée de vie s'effondrent en raison des pratiques peu scrupuleuses des exploitants des Appalaches. Je m'appuie sur la recherche écologique, les documents historiques et mon propre travail ethnographique sur le terrain pour soutenir que nous devons mieux comprendre les données démographiques de la population de ginseng et les causes de son déclin. Nous ne devrions pas cibler ceux qui dépendent de cette plante énigmatique et qui, dans de nombreux cas, ont contribué à sa gestion. Cette recherche témoigne des tensions croissantes entre les moyens de subsistance ruraux et les efforts de conservation dans le monde entier.

Mots-clés: Appalaches, moyens de subsistance en forêt, ginseng, conservation des plantes, écologie politique.

\section{Resumen}

El ginseng americano (Panax quinquefolius) es una especie de los bosques de los Apalaches y la planta medicinal más valiosa de Norteamérica. La búsqueda de raíces de ginseng es una importante estrategia de subsistencia en los Apalaches. La disminución de las poblaciones de ginseng es motivo de preocupación, y los organismos estatales y federales han introducido nuevas restricciones a la recolección, así como nuevas medidas de aplicación de la ley dirigidas a los excavadores de ginseng. En este artículo cuestiono la idea de que las poblaciones de ginseng están disminuyendo debido a las prácticas sin escrúpulos de los excavadores de los Apalaches. Me baso en la investigación ecológica, los documentos históricos y mi propio trabajo de campo etnográfico para argumentar que necesitamos una comprensión más completa tanto de la demografía de la población de ginseng como de las posibles causas de su declive. Sólo entonces podremos aceptar una narrativa que priva de derechos a aquellos que dependen de esta enigmática planta y que, en muchos casos,

\footnotetext{
${ }^{1}$ Dr. Justine Law, Associate Professor of Ecology and Environmental Studies, Hutchins School of Liberal Studies, Sonoma State University, CA, USA. Email: lawj "at" sonoma.edu. Acknowledgements: this research was funded by Denison University and Sonoma State University. Thanks also to the anonymous referees who provided valuable feedback.
} 
han ayudado a cultivarla. Esta investigación aborda algunas de las crecientes tensiones entre los medios de vida rurales y los esfuerzos de conservación en todo el mundo.

Palabras clave: Apalaches, medios de vida forestales, ginseng, conservación de plantas, ecología política

\section{Introduction}

Endemic to eastern North America, wild American ginseng (Panax quinquefolius) presents a fascinating case study of human-plant interactions. American ginseng, hereafter called ginseng, is a long-lived forest understory plant valued primarily for its root, which grows underground throughout the plant's life and which is believed to have various medicinal properties. East Asian consumers, in particular, prize mature wild ginseng for its gnarly, almost human-like shape and are willing to pay steep prices for these high-quality ginseng roots. Ginseng, in fact, was one of North America's first international trade commodities. As early as the 1780s, ginseng harvesters, or "diggers", began shipping tons of the root overseas (Taylor 2006). By 1880-1889, America were shipping nearly 7 million tons (7.1m metric tonnes) of ginseng to East Asia, and ginseng digging on the de facto forest commons had become an important source of income for Appalachian families (Carlson 1986). These mushrooming ginseng exports, however, prompted speculation about the impact of harvesting on ginseng populations and, eventually, led to the its regulation. Still, harvesting has continued, and, even today, in an era when American exports are much lower than they were at their peak in the late $19^{\text {th }}$ century, ginseng digging remains a significant livelihood strategy in Appalachian communities. For a variety of reasons though, concern for ginseng populations is escalating, creating a tension between on the one hand, maintaining ginseng populations and, on the other, maintaining forest livelihoods. This tension is the focus of this article.

Much of the concern for Appalachian ginseng populations emerges out of academic and agency discourse, but even the popular media has jumped into the fray, with sources like National Public Radio (NPR), National Geographic, and The Wall Street Journal publishing stories on ginseng in recent years (e.g. Maher 2014; Ari 2018; Rene 2020), and popular television shows like Appalachian Outlaws and Smokey Mountain Money broadcasting in 2014 and 2015. As a result, a normal narrative around ginseng has emerged: wild ginseng populations are crashing due to the unscrupulous practices of Appalachian ginseng diggers. This narrative has some merit; however, it is incomplete. And, importantly, over the last decade, it has inspired numerous state and federal policies that further restrict ginseng harvests and law enforcement efforts that target ginseng diggers. I aim to show here, however, that we need a fuller understanding of ginseng population demographics and the potential causes for ginseng decline before we embrace a narrative that demonizesand, ultimately, disenfranchises - those who depend on and, in many cases, have helped steward this enigmatic plant.

This work builds on the insights of political ecologists and others scholars who foreground the deep ecological knowledge and sophisticated environmental management practices of peoples who derive at least part of their livelihood from plants and animals (Robbins 2011). This body of scholarship also challenges environmental policies that negatively affect such peoples. More pertinent to this research, previous work has demonstrated the environmental stewardship traditions of Appalachian communities who often enhance conservation efforts (e.g. Hufford 2002; Newfont 2012; Law and McSweeney 2013). The same has been written about North American wildcrafters (e.g. Emery and Pierce 2005; Emery and Barron 2010; Grabbatin et al. 2011). For example, Barron and Emery (2012: 1007) conclude that morel mushroom hunters in the Pacific Northwest have sophisticated local ecological knowledge and are "invested in and would work toward creating effective management strategies aimed at resource sustainability", despite being "frustrated by the regulation of an activity they have been engaging in for generations." Meanwhile, Hufford explicitly ties human-ginseng interactions to the maintenance of robust commons in Appalachia: "On Coal River, knowledge and appreciation of the forested commons is fostered by sustained engagement, not detached viewing...among the means of keeping the commons alive is talk about ginseng: where to hunt it, its mysterious habits, the biggest specimens ever found, and the difficulties of wresting the treasure from an impossible steep terrain" (2002: 114).

Further, a very recent focus of environmental geography is the militarization of conservation (e.g. Büscher and Fletcher 2019; Duffy et al. 2019; Neimark 2019; Massé 2020). This body of work recognizes the value and vulnerability of many spaces and species; however, its authors argue that strategies emphasizing 
conservation law enforcement misdiagnose the causes of vulnerability, concentrating too much on catching "bad poachers" and too little on the perverse socioeconomic systems that push already-marginalized peoples further to the margins. Most of this research, however, concerns itself with poaching in Africa and Latin America. Thus, ginseng conservation provides us with a novel example of the entanglements between increasingly militant conservation strategies, such as undercover sting operations and embedded chips and dyes, and rural livelihoods in the North American context.

In the next section, I provide background information on ginseng's ecology and its history in eastern North America. Next, I overview my research methods. I then lay out the normal narrative around ginseng and its evidence base. I introduce my counternarrative, which problematizes claims about ginseng population decline, largely by situating those claims into a wider geographic and historical context, as well as claims about ginseng diggers' poor stewardship of the resource. I conclude with suggestions for the conservation and management of ginseng in Appalachia.

\section{Background}

Ginseng grows throughout eastern North American temperate deciduous forests. Its ideal habitat, however, is the well-drained, calcium-rich, mesic slopes of mixed mesophytic forests. Each spring, a ginseng plant sends up an aerial stem, which dies back each fall and leaves a scar on the belowground root, which continues growing throughout the plant's life (Figures 1 and 2). These scars make it possible to age the root. The aerial stem also adds more compound leaves, or "prongs", as the plant ages. Usually, ginseng takes at least five years to become a mature three-prong plant and to begin producing an appreciable quantity of red berries, which emerge from either self-pollinated or cross-pollinated flowers in late summer. The seeds from these berries take at least two winters to germinate. Ginseng is also cultivated in monocultures under shade structures, but cultivated ginseng-which represents the bulk of U.S. ginseng exports, is much less valuable, and comes primarily from Wisconsin-is not the subject of this article.

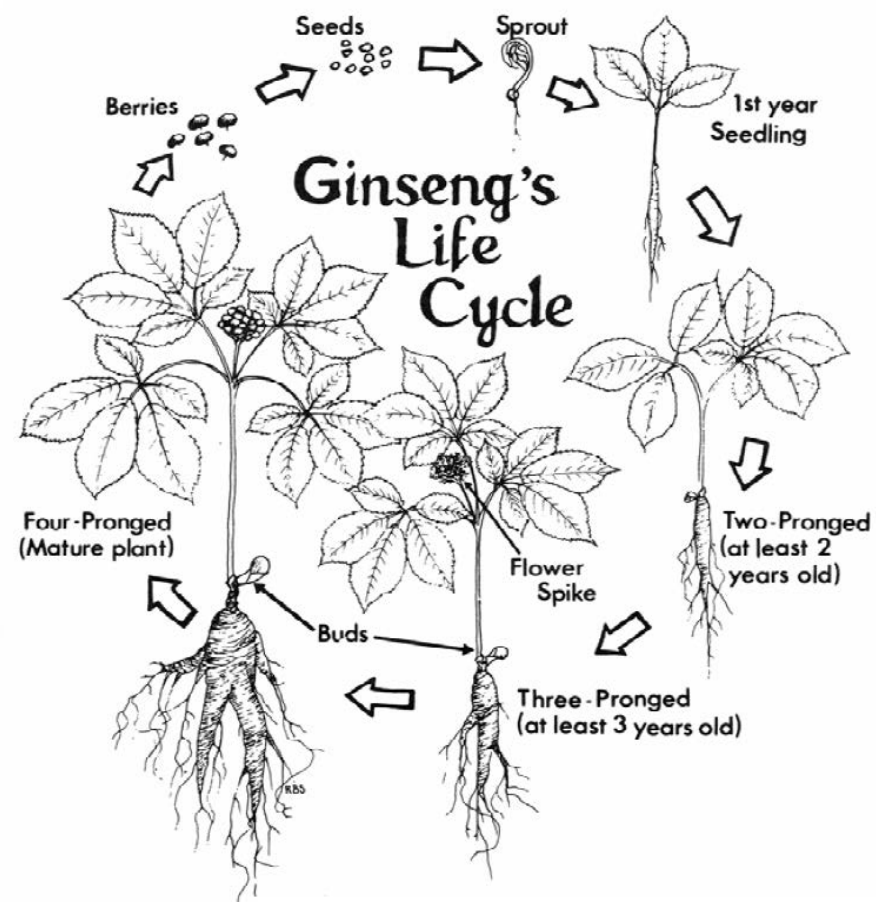

Figure 1: The life cycle of American ginseng (Panax quinquefolius). Image from Davis, J. and S. Persons. 2014. Growing and marketing Ginseng, Goldenseal, and other woodland medicinals. New Society Publishers. 


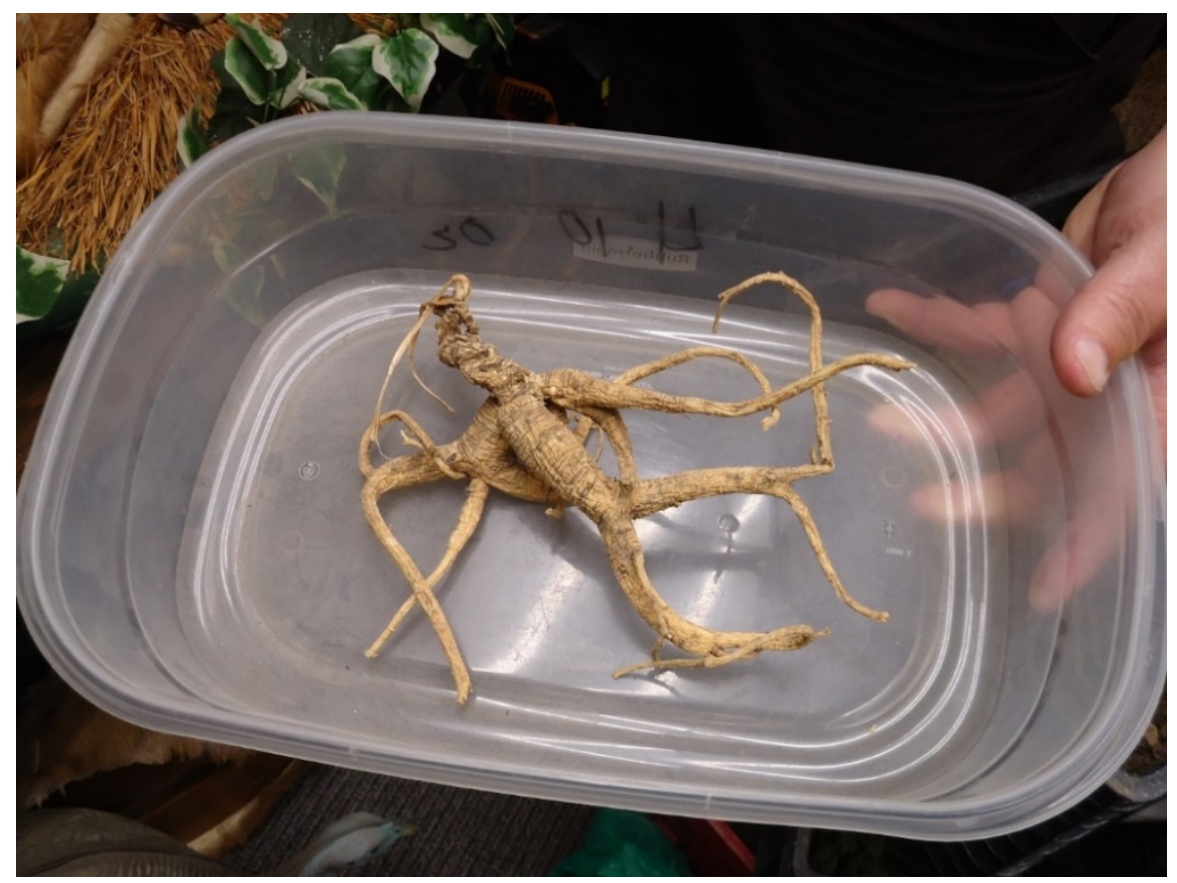

Figure 2: Mature ginseng root. Photo by author

Due to concerns about the plant's conservation status, ginseng was listed under Appendix II of CITES in 1975. Since that time, the U.S. Fish \& Wildlife service requires all harvested roots be at least five years old and certified for sale. Most management, though, is carried out at the state level. Each state has its own set of regulations vis-à-vis ginseng; some regulatory commonalities across all states include: a harvest season, which typically extends from September 1 through late fall; written permission to harvest from private land; a requirement to have three-prongs; seed planting at the harvest site; and certification through a state dealer or inspector. Moreover, both federal and state governments have been tightening ginseng regulations and restricting access to public lands in recent years. For example, some state and national forests have banned ginseng harvesting, while others have instituted ginseng permit lotteries.

The states that export the most ginseng are traditionally Kentucky, West Virginia, Tennessee, Virginia, North Carolina, Indiana, and Ohio (Schmidt et al. 2019), with each state reporting harvests of approximately 3,000-10,500 pounds (1,360-4,763 kg) of dry roots from 2015-2017 (Kruger and Munsell 2020). Over the last two decades, the value of U.S. ginseng exports have been over US\$25 million annually (Chamberlain 2018), with tens of thousands of diggers often selling dry ginseng for over US\$500 - and sometimes over US\$1000_ per pound (US\$1,100-US\$2,200/kg).

\section{Methods}

I conducted approximately four months of fieldwork from fall 2016 through the summer of 2019, primarily in southern Ohio, West Virginia, and northern Virginia. I chose these study regions for a variety of reasons. First, I wanted to focus on regions that have substantial annual ginseng harvests; the counties I spent time in, for example, exported an average of approximately 150 pounds $(68 \mathrm{~kg})$ of dry ginseng annually from 2015-2017 (Kruger and Munsell 2020). Second, I wanted to include as many land ownership categories as possible. As a result of this decision, I was able to visit numerous state park, state forest, state nature preserve, national park, national forest, private, and corporate forest lands. Third, and finally, my fieldwork options were constrained by my status as a State of California employee, which prohibited work-related travel to a number of Appalachian states. 
My fieldwork was primarily ethnographic. I conducted 18 formal interviews, which were recorded and later transcribed, and approximately 15 informal interviews. These interviews were with botanists, state and federal natural resource agency staff, state wildlife officers, ginseng diggers, ginseng growers, researchers, and nonprofit staff (Table 1). Most interviews lastly approximately 1 hour; however, some informal interviews lasted less than 15 minutes, and some formal interviews lasted the majority of the day. I identified interview subjects through a mixture of purposive, snowball, and convenience sampling strategies. I also conducted participant observation at a 3-day ginseng growers' workshop, at two conferences, and over three private Facebook ginseng digger group pages. Archival research in six collections was primarly to locate historical accounts of ginseng populations. I visited numerous forest sites, including three ginseng growing sites, and evaluated hundreds of pages of documents (e.g. ecological research, historical, and policy documents). Afterward, I coded the transcribed interviews and other collected data using thematic analyses.

For the purpose of this article, and due to the sensitive-and, often, federally-classified — nature of some of the data, I have omitted most personal names, agency names, and specific geographic locations. In other words, a Virginia national park botanist might become "botanist" here.

\begin{tabular}{|l|l|l|}
\hline Classification & n & male/female \\
\hline Ginseng digger & 11 & $11 / 0$ \\
\hline $\begin{array}{l}\text { Natural resource agency (e.g. United States Forest } \\
\text { Service, West Virginia Division of Forestry) staff }\end{array}$ & 8 & $5 / 3$ \\
\hline Nonprofit staff & 6 & $4 / 2$ \\
\hline State wildlife officer & 5 & $5 / 0$ \\
\hline Researcher & 5 & $4 / 1$ \\
\hline Botanist & 4 & $1 / 3$ \\
\hline Ginseng grower & 3 & $3 / 0$ \\
\hline
\end{tabular}

Table 1: Interview subjects by classification. Note: some interview subjects fall into multiple classifications (e.g. a nonprofit employee might also be ginseng grower).

\section{The normal narrative around ginseng management}

Although there is some heterogeneity in current discussions around ginseng management, the overall thrust of the discussion coalesces around a narrative that goes something like this: first, ginseng populations are crashing throughout Appalachia. In the popular media, for example, a recent Smithsonian article notes that the plant is becoming endangered (Taylor 2016), while an episode on NPR's All Things Considered was succinctly titled "Supplies of valuable ginseng root diminishing" (Ari 2018). Meanwhile, in the academic literature, a number of studies over the past two decades document declines in at least half of monitored study populations (e.g. Rock et al. 1999; McGraw et al. 2010; McGraw 2017; Oliver et al. 2017) and extrapolate from that data that ginseng populations are declining across the Appalachian region. For example, Oliver et. al. expand from their research across 65 sites in Indiana and Illinois to the ginseng plant's broader Appalachian range: "While ginseng has a broad distribution comprised of many populations, research suggests that ginseng populations have been steadily decreasing" (2017: 103). In my interviews, I regularly heard comments such as, "I go out to [redacted] State Forest and try to find ginseng and, yeah, I can find it, but there should lots more of it" (wildlife officer). In sum, most ginseng discourse repeatedly makes the point that ginseng is an "overexploited resource" across its range (Frey et al. 2018) and that "the future outlook...is not promising" (Chamberlain et al. 2019).

Many scholars and practitioners are concerned about ginseng population dynamics as well. For instance, as with most species, the existence of too many small, remote ginseng populations can compromise its genetic diversity, which would make the plant less resilient to environmental changes such as climate change. This 
issue is raised in the scientific literature (Cruse-Sanders and Hamrick 2004; Young et al. 2017) and by ecologists I interviewed. The literature also raises two other population-level concerns: the age structure of populations shifting to smaller, nonreproductive one-to-two-prong plants as larger plants are effectively highgraded (Van der Voort et al. 2003; Case et al. 2007) and a corresponding evolutionary shift to smaller plants overall (McGraw 2001; McGraw et al. 2010). As a result, many diggers, dealers, and botanists report that individual roots are smaller than they were a generation ago.

The next part of the standard ginseng narrative focuses on the cause of population decline and population-level change. Now, to be clear, more nuanced articles (e.g. McGraw et al. 2013; Chandler and McGraw 2015) do acknowledge the existence of multiple pressures on ginseng populations (e.g. deer browse, which can kill a plant over time; recent dry conditions due to climate change; habitat loss); however, ultimately, population decline is attributed to digger behavior. Looking back to the popular media, the title alone of a recent National Geographic article, "Demand for ginseng is creating a 'wild west' in Appalachia", makes the position of the author clear (Rene 2020). In white papers and the academic literature, the argument is nearly as blunt. For instance, the USDA Forest Service's Conservation Assessment for American Ginseng concludes that "the biggest threat to Panax quinquefolius is the intense and destructive root harvesting that the populations endure" (Kauffman 2006). Similarly, McGraw et. al. (2010: 208) note:

More disturbing is the evident willingness of diggers to violate [state harvesting regulations], suggesting either that they do not understand the reason for the rule or that violation of regulations is so commonplace that it is accepted culturally.

Further, Chamberlin et. al., in their recent review of the conservation status of non-timber forest products in the U.S., assert: "With open access resources, like American ginseng, harvest location, timing, access, and the number of harvesters is typically unrestricted. This places natural populations at risk of overexploitation and decline" (Chamberlain et al. 2019: 7). Many other articles (e.g. Van der Voort and McGraw 2006; Schmidt et al. 2019) reference Hardin's tragedy of the commons (Hardin 1968); indeed, the theory that communities cannot manage shared open-access resources remains as firmly ingrained in narratives around ginseng management as it does in most environmental management discourse.

My research participants, particularly those working for natural resource agencies, often blamed unscrupulous diggers for potential ginseng population declines as well. And some of this blame is applied harshly. For example, while showing an image of money that one digger posted on Facebook, one researcher said, "this is level of education and social interaction that's been happening...this is all ginseng means to people." Others called diggers "uneducated", "weaselly", and people who "don't know botany." Diggers themselves, in fact, occasionally critique other diggers, saying, for example: "But it's these new kids today that's wanting dollar, dollar, dollar." Other researchers who have conducted interviews with ginseng stakeholders report similar sentiments (e.g. McBride 2005; Edwards 2011; Burkhart et al. 2012).

One hypothesis I regularly heard, but which is not represented as well in the literature, is that the drug trade is driving irresponsible digger behavior. This connection to the drug trade may represent a new trend inand challenge for-ginseng management and would not be surprising given the precipitous rise in opioid addictions in Appalachia (Schalkoff et al. 2020). Two different wildlife officers, for example, explained the problem:

You got to understand that a lot of the people that we catch digging ginseng out of season don't have jobs. A lot of them will be convicted felons with some kind of a substance abuse problem, so they necessarily can't go hold down a job, but they can go out and dig ginseng every day. Being brutally honest, most of these people, they're desperate and they don't care. It's money and it's just the way that they can get their fix. So, a guy goes out and digs a half pound of green ginseng out of season. He'll take that and may get paid cash or may be given drugs directly for it. A trade. The drug trade and the illegal ginseng activity, they just go hand in hand down here in Appalachia. 
They don't need no money; they just need the pills. Them guys will come in and shake a pill bottle and say, "Hey, man, I'll get you some ginseng. I'll be back in the morning." And they will work every day. They'll get all high and messed up going up the hills to dig everything they can.

Law enforcement officers were especially likely to make this connection; however, I heard similar comments from state natural resources agency staff, as well as a few diggers.

The final component of the normal ginseng narrative includes suggestions for how to best manage the species. As noted earlier, officials working for a number of states, national forests, and other public lands have chosen to ban ginseng harvesting. For instance, Maryland banned all harvest on state lands in 2013; Daniel Boone National Forest in Kentucky instituted a harvest suspension in 2016, and it has extended it into each of the following years. In 2021, Nantahala and Pisgah National Forests in North Carolina and Cherokee National Forest in Tennessee suspended all harvesting. Together, these national forest suspensions represent over 2,350,000 acres (951,000 ha) of mixed mesophytic Appalachian forest land, as well as much of the land that was publicly, legally accessible to ginseng diggers. Taking this a step further, some scientists and stakeholders advocate banning all ginseng harvest in the U.S. Charron and Gagnon (1991: 443), for example, conclude in their demographic simulation study that "despite the fact that some populations may support reasonable and regulated harvesting, this does not imply that harvesting should be allowed." Kaufmann (2006) likewise concludes that "harvesting should not be allowed." Indeed, a number of stakeholders I spoke with either expressed the hope that ginseng harvest would be made illegal or a concern that it would be in the near future.

Other participants in these ginseng policy debates, though, do not advocate for banning harvesting. Some feel, like Chamberlin, that we need to:

Talk about conserving an industry; because the plants on which it is based are being overharvested; because the habitats that provide the plants are being converted; because the people, and their way of life, who depend on this industry will be permanently affected if we don't (2006: 5).

One policy mechanism that many stakeholders advocate for is a digger license or permit. Essentially, this means that ginseng diggers would purchase a license or permit each year through the state, much in the way that fishers purchase a fishing license or hunters purchase deer tags. At this point in time, the only states that require a ginseng license or permit are Illinois, Iowa, Maryland, Vermont, and Wisconsin—all states with relatively few annual ginseng exports.

Most call for increased law enforcement vis-à-vis ginseng, and harsher penalties for offenders. One presenter at a ginseng grower workshop, for instance, said that we need to replace the term "poacher" with the term "thief" and proposed that "that [digger] should be put in jail as if he stole your car" (state extension representative). These calls have been heeded in a number of states and on a number of public lands, especially since in the mid-2010s. Broadly, this looks like steeper fines and/or longer sentences for offenders, more training for wildlife officers, and the utilization of informant networks, canine programs, sting operations, and heightened surveillance strategies. In 2018, for example, West Virginia passed legislation to increase ginseng fines from US $\$ 100$ to US\$500-\$1,000 for a first offense (e.g. digging on prohibited land) and US $\$ 1,000$ $\$ 2,000$ - plus, in some cases, a 6-month prison sentence-for subsequent offenses. In other states, penalties can vary from relatively small fines (e.g. \$150) to fines that are insurmountable to most diggers (e.g. \$2,000) and even prison sentences. In Ohio, for instance, one wildlife officer says:

I haven't had a lot of trouble with convictions. But it depends on the court. So, a person that goes out and digs ginseng illegally, they might get $\$ 100$ or $\$ 150$ fine in [redacted] county. Now, I can go to another county in my district, and you're dealing with a prosecutor or a judge that owns property, and they might put that person in jail for over a month. 
To prepare wildlife officers, county sheriffs, and state troopers for enforcing ginseng regulations, many states began including mandatory ginseng workshops in their academy training programs in the 2000s and 2010s, and most offer additional career development ginseng workshops throughout the year. This increased training has translated into increased enforcement. For example, in the mid-2010s, Ohio's wildlife investigator program started focusing almost exclusively on ginseng during the summer and fall months, and the state began a K-9 ginseng program in 2018. Many states also began employing more covert, militant tactics around this time. As one wildlife officer describes:

I've got informants in my back pocket that I know that does drugs. It's just part of law enforcement. It's how we do business. I know they walk both sides of the fence, so if I give them a break on something, they'll give me information back...a lot of times, [on] some of these big cases that we've made, we'll take a digger and turn him over right there and tell him we'll give him a break if he gives us information, tells us where he's selling, who's buying it. Or a lot of times we'll let him do a deal for us and maybe slip one of our guys undercover with him. Usually, we wear camouflage and are dirtied up [for the sting operation]. And we've done our homework and we always have a meeting before we go and lay everything out: where the house is, the entrance points, the buildings. We try to know how many people is going to be there and so we can go in tactically.

Even more clandestinely, Appalachian national parks are applying powdered dyes, which can be detected easily by a ginseng dealer, and traceable stainless-steel microchips, which can be detected with an x-ray or a strong magnet, to ginseng roots that are later replanted by national park staff (Rock et al. 1999; Taylor 2016). Park law enforcement uses these dyed and microchipped roots to track and apprehend people who have taken ginseng from the park.

The result of all of this increased law enforcement is, in many states, a rising number of ginseng convictions per year. In Ohio, for example, annual ginseng arrests rose from 46 in 2013 to 152 in 2015 (Lane 2015), and they have continued to rise since 2015 (An 2019). In fact, in 2019, a single Ohio county posted 142 arrests (An 2019). Similarly, in West Virginia, the state Ginseng Coordinator says that they "started seeing an increase in violations around 2015...violations and citations have increased in the six years since the state Division of Natural Resources (DNR) Law Enforcement started focusing on early harvesting" (West Virginia Department of Commerce 2020). Representatives from agencies in North Carolina, Virginia, and Indiana also have spoken publicly about the rising number of ginseng arrests and convictions since the mid-2010s in their states (Chávez 2014; Sapp 2016; WDRB Media 2017). The most publicized of these convictions are the convictions of illegal buyers who are associated with the drug trade-and who are the typical targets of the sting operations described above; however, wildlife officers from multiple states attest that the majority of ginseng arrests and convictions are of diggers, who are typically lower-income and, as one wildlife officer explains, unable to pay fines for illegal digging without the help of family members.

Lastly, normal narratives often propose wild-simulated ginseng cultivation as a way to bolster wild ginseng populations. Wild-simulated cultivation differs greatly from traditional cultivation: growers plant ginseng seed under their own existing forest canopy in minimally-disturbed beds and with minimal inputs. The seed, however, usually is obtained from traditional growers in Wisconsin. This wild-simulated method, which recreates wild ginseng's typical environment, produces cultivated roots that are often indistinguishable from wild roots. And the goal, ultimately, is for these wild-simulated roots to replace-or at least mostly replacewild roots in ginseng markets. Tellingly, proponents of this strategy call it "conservation through cultivation." My research participants working on wild-simulated cultivation estimate that, at this point, there are hundreds of wild-simulated growers throughout the eastern U.S.

\section{A Ginseng counternarrative}

To begin with, it is important to acknowledge that the normal narrative does make important contributions to our understanding of wild ginseng and its conservation. Clearly, for example, ginseng 
populations have declined from the days when, as botanist William Bartram noted in 1776, it "appear[ed] plentifully" on north-facing slopes in the southern Appalachians (Manget 2012). Also, scientists, park and forest staff, and diggers themselves do report the existence of small populations with low genetic diversity in parts of Appalachia. Such populations surely will have more trouble withstanding frequent harvests or more existential threats such as climate change. Lastly, there does seem to be an increased association between opioid markets and ginseng markets in Appalachia, which is not shocking given the immense value of both commodities. These are all very real, pressing concerns.

That said, this normal narrative is ripe for refinement. First, it does not present a complete enough picture of longer-term, geographically-distinct environmental change. More specifically, and as I argue below, my archival research demonstrates that ginseng populations have been small for generations. In other words, small ginseng populations are not a recent phenomenon. I also found that many parts of Appalachia have stable, or even increasing, populations. Second, the normal narrative arguably does not devote enough attention to socioeconomic forcings, nor does it account for the traditional ecological knowledge and environmental management practices of ginseng diggers (e.g. planting ginseng seeds) in a substantive way. Finally, as a result, this narrative risks misdiagnosing — or, at least, incompletely diagnosing — the problem and, correspondingly, recommending measures that are not as effective or socially equitable as they might be.

Let us first consider ginseng population change. The trouble is that it is nearly impossible to track ginseng populations through time because we do not have historical ginseng population data. Some studies, in lieu of historical population data, use ginseng export data to demonstrate ginseng population decline (e.g. Frey et al. 2018; Schmidt et al. 2019); however, export numbers do not necessarily correlate to population numbers. Some 500 pounds $(227 \mathrm{~kg}$ ) of exported ginseng, for example, could represent nearly all of a region's ginseng population or a small percentage of that population. Much depends on the number of diggers, the effort they expend, the number of roots they ultimately sell, the geography of harvest, and so on. Other studies use herbarium specimens to show decreases in root size and abundance (e.g. McGraw 2001; Case et al. 2007). But herbarium specimens are also unreliable proxies for actual population data. Thus, while we should not discount the claims made in this body of research, we also should not take them at face value.

Written accounts, including those I collected from various archives in my study regions, provide another source of information on historical ginseng populations. Interestingly, though, these written accounts call into question the conclusions reached by the export data and herbarium specimen research-namely, their suggestion that ginseng populations were high until relatively recently. Indeed, after the $18^{\text {th }}$ century, nearly all written accounts warn readers of impending ginseng extirpations. Consider: in 1870, one clerk noted in a letter to a botanical company that "another year will clean out the sang from the mountains" (Manget 2012); in 1894, a U.S. Department of Agriculture bulletin argued that "the natural supply is now rapidly decreasing, and its extermination, if present conditions continue, is inevitable" (Nash 1894); from 1903-1906, The Ginseng Garden agricultural periodal variably described ginseng as "died out", "about to run out", and "now almost extinct" (The Ginseng Garden [1903-1906]). In 1936, Harding reported that "it is dug whenever found, as the hunting of 'seng' is a business [in southern Appalachia], if the finder does not gather it as soon as found, some other 'digger' is sure to save him the trouble" (1936: 25). In 1970, an article in Pennsylvania Angler lamented the fact that: "the 'seng hunter of today is apt to find the objects of his quest few and far between. Indeed, an expert in the art of finding wild ginseng may travel all day in traditional 'seng country and never spot a single stalk" (Savage 1970); and, in 1997, The West Virginia Hillbilly noted that "ginseng's getting rare" (McCauley 1997). We should not take these written accounts at face value either; however, they do trouble the overlysimplistic, often-ahistorical narrative that ginseng populations are crashing throughout Appalachia today, and they suggest that Appalachia never had abundant ginseng populations after the mid-19 ${ }^{\text {th }}$ century.

Indeed, the fact that ginseng is still found throughout Appalachia demonstrates that it is more resilient than often described. From the middle $19^{\text {th }}$ through early $20^{\text {th }}$ centuries, logging, coal mining, charcoal production, and other extractive industries precipitated the deforestation of the majority of the eastern U.S. (Williams 1992; Yarnell 1998). Ginseng populations, therefore, have been rebounding from limited refugia since this industrial era. Notably, some scholarship references this history (McGraw et al. 2013; Chandler and McGraw 2015), but does not emphasize it. And, while this rebound could be interpreted as a result of increased conservation, the rebound timeline does not align with the timeline of stringent conservation measures, which 
occurred more recently. Nor have Appalachian ginseng exports decreased since the industrial era (Carlson 1986).

Furthermore, in a number of state and federal lands throughout southern Ohio, West Virginia, and northern Virginia, botanists and other natural resource staff report that ginseng populations are stable. In one national forest, for example, the botanist reports that "the estimated population hasn't really changed too much...there's not a day that goes by where if I'm in the woods I don't see it. It's pretty much everywhere on the hills." Similarly, a park botanist was surprised to see that the current age distribution of monitored ginseng populations in the park matches the age distribution in the 1970s and said, "we have a lot more ginseng that we thought." Meanwhile, at a state forest, a ranger excitedly proclaimed that "there's tons of it out there!" Overall, more than half of my research participants believed ginseng populations in their park or forest were stable or increasing, and there was widespread agreement about these assessments among stakeholders (i.e. stakeholders were not giving contradictory accounts of local ginseng populations). This does not, as mentioned earlier, mean that some locations are not experiencing worrying population declines, but it does indicate that such declines are not geographically homogenous.

Turning our attention to the causes of ginseng population change, I again wish to add a number of asterisks to the normal narrative. To begin with, it is important to recognize that society has vilified diggers for as long as people have been digging ginseng. Kains, for example, claimed that "the principal agents in the extermination of the native supply are the ginseng diggers...they exercise no judgement whatever in collecting" (1903: 13), while Harding called diggers "poor, ignorant people" with "shiftless" methods (1936: 23-24). Now, I do not mean suggest that this is a boy-crying-wolf scenario in which every accusation against diggers is inaccurate-including contemporary allegations. However, it does suggest that diggers' behaviors today are perhaps not so different from diggers' behaviors in past decades. My research participants, for example, describe how their fathers and grandparents used to harvest ginseng in the summer, on private land without permission, and on prohibited public land, all illegal practices that are corroborated by others' research (e.g. Pokladnik 2008; Turner 2015). Furthermore, while it is certainly true that ginseng has some entanglement with the Appalachian drug epidemic now, it is also true that ginseng digging is increasingly criminalized. Thus, increased arrests and convictions may be due, at least in part, to increased surveillance and law enforcement efforts.

Casting diggers as the problem also, importantly, overlooks the fact that diggers can be, and have been, beneficial for ginseng populations. All of those I spoke with, for example, talked passionately about their efforts to propagate ginseng:

We've got patches of ginseng that are hidden back in the woods that people wouldn't know about, and we just kind of cultivate it, for lack of a better word by, you know, leaving some of the bigger plants there. And dad and I will go out, and we find it and plant the berries. That's a big thing we do is we go out every year, and we help the berries go in the ground. And that's pretty simple. Just grab a stick and just jab it about half an inch into the ground, drop [the seed] down in there, and throw some leaves and little dirt on it. (digger)

Again these practices are corroborated by other research with diggers (e.g. McBride 2005; Pokladnik 2008; Edwards 2011). Other stakeholders noted that "I mean, generally [diggers here] know the sustainable practices; that's my rough feel" (national forest botanist), and the private message boards of Facebook digger groups are also instructive. Moreover, in population simulations, responsible "steward" digger behavior caused populations to grow by $4 \%$ annually, and unpublished experimental data shows that planted ginseng seeds are 7.6 times more likely to germinate than seeds that fall on the forest floor (Van der Voort and McGraw 2006). All of this will not be surprising to political ecologists, who often reveal that people who depend on natural resources are highly capable of stewarding them.

Lastly, the normal narrative's overly-narrow focus on diggers causes us to neglect other causes of ginseng decline, such as: land use change and suburban sprawl (Johannsen 2006). Surface mining, which has razed approximately 1.5 million acres $\left(6,070 \mathrm{~km}^{2}\right.$, a little larger than Delaware) in central Appalachia since 
1970 (Pericak et al. 2018) is only one cause. There are also climatic changes-especially increased summer temperatures (Souther 2011); deer browse, which has increased as deer populations have exploded in the eastern United States since the mid 20 ${ }^{\text {th }}$ century (McGraw and Furedi 2005; Oliver et al. 2017); and the presence of invasive species (Oliver et al. 2017). As one respondent in Burkhart et al.'s study succinctly states: "wildcrafters rarely did a colony of ginseng out of existence. Bulldozers always do" (2012: 3675).

All of these broader qualifications matter because, if we want ginseng policy and management to work, we need to address the full range of causes for possible population decline. For example, many of my research participants conclude, alongside some researchers, that more bans and permits will not prevent illegal harvest. As one national forest botanist says, "if you make it illegal to harvest, they're going to keep doing it just like their grandparents did...it's just part of their culture." Law enforcement, meanwhile, can end up targeting responsible diggers who harvest from what they view as the forest commons (e.g. state forestland, coal company land):

Well, I've had plenty of times in my career where people actually do wait til season comes in, but they still might go to state forest property to dig even though it's illegal. It seems like that older generation, they just can't understand that you have to have written permission to go out in the woods and dig ginseng. There's a mindset of, "Hey, I grew up doing this. This has always been okay. What's the problem now?" I've got a pastor that lives not far from where I live and I've caught him three times now, and he's a great guy. But he'll dig ginseng on state property, and in his mind, he's justified in what he's doing. (wildlife officer)

This, ultimately, is a criminalization of the very people and behaviors that have stewarded the plant for generations. This is an argument others have made when discussing so-called "folk crime" (e.g. Barron and Emery 2012; Duffy et al. 2019). Finally, the "conservation through cultivation" movement, while laudable in its goals and its contributions to ginseng population growth, represents a privatization of traditional commons practice. To be clear, this movement is distinct from diggers simply planting small patches throughout the forest because it frequently advocates for wild harvesting restrictions, such as the harvesting ban on West Virginia state lands. This is inequitable because many ginseng diggers are lower-income and do not own their own forestland; they rely on access to public and company land, and closing off access to these de-facto commons only serves to close off a livelihood opportunity that so many depend upon.

\section{Conclusions}

So what should we do? As I have explained, there are reasons to be concerned about this ecologically and economically vital plant-although the degree, timeline, geographic scope, and cause of ginseng population decline is unsettled. Nonetheless, we have to de-simplify the narrative that is currently taking up the most terrain in both popular and academic discourse. We need to consider a longer history of ecological and land use change; we need to contextualize the criticism of diggers within the historical social discourse and broader socioeconomic structures; and we need to highlight the crucial stewardship practices of diggers. This wider lens may lead us to different policy and management strategies as well.

More specifically, I propose the following conservation strategies. First, there is an urgent need for more data on ginseng populations. We simply do not have enough data to make well-informed management decisions. To collect this data, we might leverage the ecological knowledge of diggers themselves and develop citizen science projects that put GPS units_or even just field journals_-into the hands of willing volunteer diggers. Diggers regularly scout ginseng populations throughout the summer anyway, so we might employ them to collect population data during this offseason and on land where harvest is legal. Second, and relatedly, we might engage these diggers in a widespread ginseng planting effort on public land, ideally with native seeds. Diggers understand the plant, know its ideal habitat, and could facilitate a region-wide ginseng resurgence, which, arguably, would outweigh any concerns about genetic pollution. We might compensate diggers for both of these efforts with grant funding or, where appropriate, access to ginseng resources. Indeed, a third recommendation is to reinvigorate the Appalachian commons by creating lease systems and other cooperative 
management programs for registered diggers on public lands. A number of innovative programs, for example, have built networks of local stakeholders who manage resources (e.g. firewood, mushrooms) on public land in exchange for harvest rights (e.g. Lynch et al. 2004; Law 2017), and we might apply a similar model to ginseng. All of these efforts (i.e. data collection, planting, and cooperative management) should be co-led by respected, long-time local diggers, who could be identified by word of mouth—or even through the many highly-active Facebook digger groups. Finally, rather than asking already-overextended wildlife officers to chase diggers through the forest, a more effective way to prevent diggers struggling with addiction from violating ginseng laws would be to treat addiction and its causes directly (e.g. via more robust rehabilitation programs). This approach may be less politically palatable in such a politically conservative region, but it surely would have beneficial impacts on all dimensions of Appalachian life.

I submit that, overall, these strategies would be more just to local people, and more effective at conserving Appalachian ginseng populations, than the strategies we have come up with so far. More broadly, these strategies and this counternarrative speaks to and can help shed light on the tension we find between rural livelihoods and increasingly exclusionary and law-enforcement-driven conservation efforts in all corners of the globe.

\section{References}

An, A. 2019. Ohio officials: criminals turning to ginseng poaching for big payoff. 10tv.com. July 11.

Ari, S. 2018. Supplies of valuable ginseng root dwindling. All Things Considered. Radio broadcast, npr.org. January 25.

Barron, E. S., and M. R. Emery. 2012. Implications of variation in social-ecological systems for the development of US fungal management policy. Society \& Natural Resources 25: 996-1011.

Burkhart, E. P., M. G. Jacobson, and J. Finley. 2012. A case study of stakeholder perspective and experience with wild American ginseng (Panax quinquefolius) conservation efforts in Pennsylvania, USA: limitations to a CITES driven, top-down regulatory approach. Biodiversity and Conservation 21: 36573679.

Büscher, B., \& Fletcher, R. 2019. Towards convivial conservation. Conservation and Society, 17(3): 283-296.

Carlson, A. W. 1986. Ginseng: America's botanical drug connection to the Orient. Economic Botany 40: 233249.

Case, M. A., K. M. Flinn, J. Jancaitis, A. Alley, and A. Paxton. 2007. Declining abundance of American ginseng (Panax quinquefolius L.) documented by herbarium specimens. Biological Conservation 134: 22-30.

Chamberlain, J. L. 2006. Conserving the Appalachian medicinal plant industry. In Proceedings, Fourth Annual Symposium on Appalachian Opportunities-Medicinal and Aromatic Plants. Pp. 5-16.

Chamberlain, J. L. 2018. Assessment of nontimber forest products in the United States under changing conditions. USDA Forest Service. https://doi.org/10.2737/SRS-GTR-232

Chamberlain, J., C. Small, and M. Baumflek. 2019. Sustainable forest management for nontimber products. Sustainability 11: 2670-2690. https://doi.org/10.3390/su11092670

Chandler, J. L., and J. B. McGraw. 2015. Variable effects of timber harvest on the survival, growth, and reproduction of American ginseng (Panax quinquefolius L.). Forest Ecology and Management 344: 19.

Charron, D., and D. Gagnon. 1991. The demography of northern populations of Panax quinquefolium (American ginseng). The Journal of Ecology: 79(2): 431-445.

Chávez, K. 2014. Forest Service ginseng permits stay at reduced level. The Asheville Citizen Times. June 8.

Cruse-Sanders, J. M., and J. L. Hamrick. 2004. Genetic diversity in harvested and protected populations of wild American ginseng, Panax quinquefolius L. (Araliaceae). American Journal of Botany 91: 540-548.

Davis, J. and S. Persons. 2014. Growing and marketing Ginseng, Goldenseal, and other woodland medicinals. New Society Publishers. 
Duffy, R., F. Massé, E. Smidt, E. Marijnen, B. Büscher, J. Verweijen, M. Ramutsindela, T. Simlai, et al. 2019. Why we must question the militarisation of conservation. Biological Conservation 232: 66-73. https://doi.org/10.1016/j.biocon.2019.01.013

Edwards, E. A. 2011. Stewards of the forest: an analysis of ginseng harvesters and the communal boundaries that define their identity in an area of environmental degradation. MA thesis, Marshall University.

Emery, M. R., and E. S. Barron. 2010. Using local ecological knowledge to assess morel decline in the US Mid-Atlantic region. Economic Botany 64: 205-216.

Emery, M. R., and A. R. Pierce. 2005. Interrupting the telos: locating subsistence in contemporary US forests. Environment and Planning A 37: 981-993.

Frey, G. E., J. L. Chamberlain, and J. P. Prestemon. 2018. The potential for a backward-bending supply curve of non-timber forest products: an empirical case study of wild American ginseng production. Forest Policy and Economics 97: 97-109.

Grabbatin, B., P. T. Hurley, and A. Halfacre. 2011. "I still have the old tradition": The co-production of sweetgrass basketry and coastal development. Geoforum 42: 638-649.

Hardin, G. 2009. The tragedy of the commons. Journal of Natural Resources Policy Research 1: 243-253.

Harding, A. R. 1936. Ginseng and other medicinal plants. Health Research Books.

Hufford, M. 2002. Reclaiming the commons: narratives of progress, preservation, and ginseng. In Howell, B.J. (Ed.). Culture, environment, and conservation in the Appalachian South. University of Illinois Press. Pp. 100-120.

Johannsen, K. 2006. Ginseng dreams: The secret world of America's most valuable plant. The University Press of Kentucky.

Kains, M. G. 1903. Ginseng: Its cultivation, harvesting, marketing and market value, with a short account of its history and botany. Orange Judd Company.

Kauffman, G. 2006. Conservation assessment for American ginseng (Panax quinquefolius) L. USDA Forest Service, Eastern Region.

Kruger, S., and J. Munsell. 2020. RootReport: spotlight on ginseng. Virginia Tech. Department of Forest Resources and Environmental Conservation.

Lane, M. B. 2015. More Ohioans digging, selling native ginseng. The Columbus Dispatch. February 26.

Law, J. 2017. The other questions we need to be asking about wood bioenergy. Journal of Forestry 115: 128133.

Law, J., and K. McSweeney. 2013. Looking under the canopy: rural smallholders and forest recovery in Appalachian Ohio. Geoforum 44: 182-192.

Lynch, K., E. Jones, and R. McClain. 2004. Nontimber Forest Product inventorying and monitoring in the United States: rationale and recommendations for a participatory approach. National Commission on Science for Sustainable Forestry.

Maher, K. 2014. Demand for ginseng boosts prices, tempts poachers. The Wall Street Journal. September 17.

Manget, L. 2012. Sangin' io the Mountains: the ginseng economy of the Southern Appalachians, 1865-1900. Appalachian Journal 40: 28-56.

Massé, F. 2020. Conservation law enforcement: policing protected areas. Annals of the American Association of Geographers 110: 758-773. https://doi.org/10.1080/24694452.2019.1630249

McBride, S. E. 2005. Political juxtapositions: wildcrafting among herb diggers in Graham County, North Carolina (1900-2004). PhD dissertation. University of Georgia.

McCauley, R. 1997. Ginseng proves valuable asset in Appalachia. The West Virginia Hillbilly, March 13.

McGraw, J. B. 2001. Evidence for decline in stature of American ginseng plants from herbarium specimens. Biological Conservation 98: 25-32. 
McGraw, J. B. 2017. Taking the broad view: how are wild ginseng populations faring and when does conservation policy need to change? In Proceedings of the Future of Ginseng and Forest Botanicals Symposium. Morgantown, WV.

McGraw, J. B., and M. A. Furedi. 2005. Deer browsing and population viability of a forest understory plant. Science 307: 920-922.

McGraw, J. B., S. Souther, and A. E. Lubbers. 2010. Rates of harvest and compliance with regulations in natural populations of American ginseng (Panax quinquefolius L.). Natural Areas Journal 30: 202-210.

McGraw, J. B., A. E. Lubbers, M. Van der Voort, E. H. Mooney, M. A. Furedi, S. Souther, J. B. Turner, and J. Chandler. 2013. Ecology and conservation of ginseng (Panax quinquefolius) in a changing world. Annals of the New York Academy of Sciences 1286: 62-91.

Nash, G. 1894. American Ginseng: its commercial history, protection, and cultivation. Bulletin No. 16. USDA Division of Botany.

Neimark, B. 2019. Address the roots of environmental crime. Science 364: 138-138. https://doi.org/10.1126/science.aax2701

Newfont, K. 2012. Blue Ridge commons: Environmental activism and forest history in western North Carolina. University of Georgia Press.

Oliver, L., A. Treher, and A. Frances. 2017. Population, distribution, and threats of American Ginseng (Panax quinquefolius L.) in Indiana and Illinois. In Proceedings of the Future of Ginseng and Forest Botanicals Symposium. Morgantown, WV.

Pericak, A. A., C. J. Thomas, D. A. Kroodsma, M. F. Wasson, M. R. V. Ross, N. E. Clinton, D. J. Campagna, Y. Franklin, et al. 2018. Mapping the yearly extent of surface coal mining in Central Appalachia using Landsat and Google Earth Engine. PLoS ONE 13. https://doi.org/10.1371/journal.pone.0197758

Pokladnik, R. J. 2008. Roots and remedies of Ginseng poaching in Central Appalachia. PhD dissertation, Antioch University.

Rene, E. 2020. Demand for ginseng is creating a 'wild west' in Appalachia. National Geographic. January 9.

Robbins, P. 2011. Political ecology: a critical introduction. Wiley.

Rock, J., H. Hornbeck, J. Tietjen, and E. Choberka. 1999. Habitat modeling and protection of American ginseng (Panax quinquefolius L.) in Great Smoky Mountains National Park. US National Park Service Report. Great Smoky Mountains National Park, Gatlinburg, TN.

Sapp, K. 2016. Ginseng poaching continues to grow, Virginia officials say. Richmond Times-Dispatch. August 6.

Savage, W. 1970. The 'seng diggers. Wonderful West Virginia.

Schalkoff, C. A., K. E. Lancaster, B. N. Gaynes, V. Wang, B. W. Pence, W. C. Miller, and V. F. Go. 2020. The opioid and related drug epidemics in rural Appalachia: a systematic review of populations affected, risk factors, and infectious diseases. Substance Abuse 41: 35-69. https://doi.org/10.1080/08897077.2019.1635555

Schmidt, J. P., J. Cruse-Sanders, J. L. Chamberlain, S. Ferreira, and J. A. Young. 2019. Explaining harvests of wild-harvested herbaceous plants: American ginseng as a case study. Biological Conservation 231: 139149. https://doi.org/10.1016/j.biocon.2019.01.006

Souther, S. 2011. Demographic response of American ginseng (Panax quinquefolius L.) to climate change. $\mathrm{PhD}$. Dissertation, West Virginia University.

Taylor, D. A. 2006. Ginseng, the divine root. Algonquin Books.

Taylor, D. A. 2016. The fight against Ginseng poaching in the Great Smoky Mountains. Smithsonian Magazine, April 21.

The Ginseng Garden [1903-1906]. Lloyd Library and Museum Collection: Ginseng Garden Publishing Co.

Turner, J. B. 2015. The root of sustainability: Investigating the relationship between medicinal plant conservation and surface mining in Appalachia. PhD Dissertation, West Virginia University. 
Van der Voort, M. E., and J. B. McGraw. 2006. Effects of harvester behavior on population growth rate affects sustainability of ginseng trade. Biological Conservation 130: 505-516.

Van der Voort, M. E., B. Bailey, D. E. Samuel, and J. B. McGraw. 2003. Recovery of populations of goldenseal (Hydrastis canadensis L.) and American ginseng (Panax quinquefolius L.) following harvest. The American Midland Naturalist 149: 282-292.

WDRB Media. 2017. Indiana DNR officials cracking down on illegal ginseng harvesting. WDRB. September 16.

West Virginia Department of Commerce. 2020. Wild ginseng survival threatened by poachers and out of season digging. West Virginia Department of Commerce. May 29.

Williams, M. 1992. Americans and their forests: A historical geography. Cambridge University Press.

Yarnell, S. L. 1998. The Southern Appalachians: A history of the landscape. USDA Forest Service, Southern Research Station.

Young, J., D. Smith, and T. King. 2017. American ginseng status assessment on four National Forests in the Mid-Atlantic U.S. In Proceedings of the Future of Ginseng and Forest Botanicals Symposium. Morgantown, WV. 